\title{
The "Flight of the Bat" and the Covid-19 Pandemic: Reflections on the Greek Experience
}

\section{"Yarasa Uçuşu" ve Covid-19 Salgını: Yunanistan Deneyimine Yansımalar Anastas PHILALITHIS $\underline{\text { ID }}$}

\author{
AP: 0000-0002-3527-3565
}

Emeritus of Social Medicine - Health Planning, Medical School, University of Crete, Greece

\section{Abstract}

The Covid-19 pandemic spread quickly after its first detection in China in December 2019, causing high mortality and morbidity globally. The lockdowns imposed to control its spread caused huge economic, social and psychological effects. Greece achieved relatively good results in terms of recorded cases, admissions to ICU and deaths. Exploring the reasons behind the success, it is shown that Greece reacted quickly, taking several difficult decisions to impose restrictions on many activities at the end of February 2020 and early March. Following the recommendations of an ad hoc Committee of Specialists, restrictions were extended in quick succession, culminating in an almost universal lockdown that started on 23 March 2020. The success in limiting the spread of the coronavirus led to a gradual relaxation of the lockdown that started on 4 May 2020. In achieving this result, credit must be given to the government that listened to the scientific advice, to the academics and health professionals involved and to the public who complied with the restrictions with remarkable forbearance. The pandemic exposed the chronic deficiencies in the country's National Health System (ESY) and the Public Health Services. Yet the hospitals responded with professionalism and effectiveness, supported by additional staff, and the Civil Protection Agency fulfilled many of the required tasks. Special care was taken to protect vulnerable populations. The economic fallout is considerable and difficult to deal with, while the blow on the tourist industry is severe, in spite of the country being a safe destination. While the management of the health crisis received inter-party political support, political controversy surrounds the proposals to mitigate the economic downturn. Several questions remain about the future, whose answers will depend on the choices made by both the citizens and their leaders.

Key words: pandemia, covid-19, healthcare system, Greece

\section{Özet}

Covid-19 salgını, Aralık 2019'da Çin'de ilk tespitinden sonra hızla yayılarak dünya çapında yüksek mortalite ve morbiditeye neden olmuştur. Yayılmasını kontrol etmek için uygulanan tedbirlerin ciddi ekonomik, sosyal ve psikolojik sonuçları olmuştur. Yunanistan, olgu saylları, yoğun bakım ünitelerine kabuller ve ölümler açısından nispeten iyi sonuçlar elde etmiştir. Başarının ardındaki nedenler irdelendiğinde, Yunanistan'ın hızla tepki göstererek 2020'nin Şubat sonu ile Mart başında birçok faaliyete kısıtlama getirmeye yönelik kararlar verdiği görülmektedir. Hemen ardından, oluşturulan geçici bir Uzmanlar Komitesi'nin tavsiyelerine uygun olarak, 23 Mart 2020'de başlayan tüm ülkede bir karantina gerçekleştirildi. Koronavirüsün yayılmasını sınırlamakta elde edilen başarıdan sonra 4 Mayıs'ta başlamak üzere karantinanın kademeli olarak gevşemesi başladı. Bu sonuca ulaşılmasında, bilimsel tavsiyelere uymuş olan hükümetin, ilgili akademisyenler ve sağlık profesyonellerinin ve olağanüstü hoşgörü ile kısıtlamalara uyan halkın katkısı büyüktür. Bu arada pandemi, ülkenin Ulusal Sağlık Sistemi (ESY) ile Halk Sağlığı Hizmetlerinin kronik eksikliklerinin gündeme gelmesine de neden olmuştur. Yine de hastaneler profesyonel ve etkin bir biçimde, yardımcı sağlık personeli ve Sivil Savunma Ajansının da katkısı ile gerekli her türlü etkin görevi yerine getirmiştir. Toplumun savunması/örselenebilir nüfuslarını korumak için özel dikkat gösterildi. Ülkenin güvenli bir tatil noktası olarak değerlendirilmesine rağmen, turizm endüstrisindeki şiddetli darbe ekonomi açısından başa çıkılması zor bir durum ortaya koydu. Sağlık krizinin yönetimi siyasi gruplar taraflar arası destek alırken, ekonomik gerilemeyi hafifletme önerileri tartışmalara neden olmaktadır. Halen, konu ile ilgili gelecekle ilgili, cevapları halk ve liderler tarafindan yapılacak tercihler temelinde verilmesi beklenen çeşitli sorular mevcuttur.

Anahtar Kelimeler: pandemi, covid-19, sağlık sistemi, Yunanistan 
In chaos theory, the flight of a butterfly in a remote corner of the planet can trigger a chain of non-linear events that may result in a major storm at the other side of the globe. In the case at hand, it was maybe during the "flight of the bat" that the corona virus jumped species from bats to pangolins $(1,2,3)$ (or was it another mammal?), and from thereon to humans. From December 2019 when the first cases were recognised in the city of Wuhan in the Hubei province of China, the SARS-COV-2 virus spread with alarming speed from one population to another, reaching every continent and every country in the world (4). So far, there are more than ten million recorded cases and more than half a million deaths worldwide, while many more people have suffered mild symptoms or have gone through an asymptomatic infection $(5,6)$. Beyond the sheer numbers of deaths and recorded cases, the Covid-19 pandemic has put enormous strain on the health services, as countries rush to treat an unprecedented surge in the numbers of patients requiring hospitalization and ventilator support, as well as carrying out diagnostic tests and contact tracing for all the cases identified. In addition, the ensuing lockdowns have had severe consequences on the global economy (7), while the full social and psychological effects will take a while to be understood and assessed $(8,9,10,11)$. It is inevitable that such a major upheaval in everybody's daily routine, whether they suffered from the disease or not, will impact the political realities of each country (12), depending on how well it coped with the crisis, and how the population perceives and judges the performance of the government.

The impact of the pandemic varied between countries. One country that fared far better than others is Greece. At the time of writing, it had recorded 3432 cases and 191 deaths, corresponding to 32.9 cases and 1.8 deaths per 100,000 . In comparison with some countries of similar population size in Europe, it is noted that Belgium had recorded 61509 cases and 9753 deaths, Czechia 12046 cases and 349 deaths, Hungary 4157 cases and 586 deaths, Portugal 42454 cases and 1579 deaths and Sweden 69692 cases and 5370 deaths (13). The present paper will present the country's response to the pandemic and attempt to explain what factors contributed to the success.

\section{The lead up to the lockdown}

When the news about the outbreak was heard, it was viewed as something that was distant and unlikely to affect the country. Then, on 30 January 2020, the World
Health Organization (WHO) declared that it is a Public Health Emergency of International Concern (PHEIC) and on the next day Italy, a neighbouring country with close business, trade and tourist links with Greece, declared a state of emergency. It was therefore deemed necessary to prepare for the outbreak (14). An ad hoc Committee of Specialists in infectious diseases, epidemiology and intensive care, was appointed on 17 February and tasked to provide relevant scientific advice. Immediate plans to reallocate specific hospitals as Covid-19 reference centres were drawn and put into place, steps were taken to recruit additional medical and nursing staff for the country's National Health System (known as "ESY", from "Ethniko Systyma Ygeias") and to increase the number of beds in the Intensive Care Units (ICU) of the ESY hospitals. When the first case of infection was confirmed on 26 February, in a woman who had just returned from a business trip to Italy, she was immediately hospitalised in a negative pressure unit, and so were the cases confirmed over the next few days, including a group of travellers who had just returned from a pilgrimage in the Middle East, almost all of whom were infected.

Public awareness of the possible scale of the problem was heightened on 27 February when it was announced that, in accordance with the advice of the Committee of Specialists, all carnival events were banned, just as everybody was preparing for the climax of festivities on the following weekend. Although official events were cancelled, groups of people in some towns defied the ban and unofficial celebrations took place, fortunately without untoward results. During the first fortnight of March, new measures were announced almost on a daily basis: initially it was local lockdowns and specific school closures, then school trips were banned and eventually all schools and universities were closed; cafes, bars, restaurants and tavernas followed; shopping centres and retail shops were shut; all sporting activities and cultural events were banned; religious services of all creeds were suspended. Public awareness was raised even further when a warning message was sent on 11 March to all the mobile (cell) phones in the country, accompanied by a distinctive sound alarm. On the next day, by coincidence, the first Covid-19 death was reported and the WHO upgraded the Covid-19 outbreak to a pandemic. During the next weeks, restrictions of arrivals by air, land and sea were gradually extended: everybody who entered the country had to quaranti- 
ne for 14 days; flights were suspended with very few exceptions; land borders were closed; ships and pleasure boats were banned from docking in Greek ports. Also, admissions to hospitals for non-urgent surgery and investigations were indefinitely postponed and regular out-patients departments were closed.

\section{The lockdown}

A general lockdown was announced on 22 March, to start on the following day. Everybody had to "stay at home", all but essential economic activities were suspended and anybody who left their home had to carry a justification for their exit, in the form either of an SMS authorization or of a signed statement. Being outside one's home was only allowed for work or for one of six specific reasons: seeking medical care, visiting a supermarket or grocery, a relative in need or a bank, personal exercise and taking a pet for a walk.

During the next weeks, the country adapted to living in lockdown. After a process of trial and error, a pattern for a daily press briefing at 6:00 pm was established. It was transmitted live on all TV channels and watched (almost) by the whole country. The briefing was carried out by the chair of the Committee of Specialists and the Deputy Minister for Civil Protection. The former, a soft spoken Professor of Infectious Diseases, presented the health aspects of the outbreak and answered all related questions, including questions about clinical matters, methods of testing, the effectiveness of different therapies and the prospects for developing a vaccine. The latter presented and dealt with all the administrative aspects. In addition, the Deputy Minister of Health answered questions about the preparedness of the hospitals and of the health services in general.

The country followed closely how many new cases were confirmed and where, how many people died and their demographics, how many patients were admitted to hospital, how many required a ventilator. One issue that was repeatedly discussed was the availability of molecular tests both for suspected cases and for contact tracing, as well as the pros and cons of antibody tests to detect those with presumed immunity. It also followed closely how many transgressions of the limitations of movement happened on each day, the imposition of additional restrictions of movement wherever a cluster of cases appeared in any part of the country or in a specific facility, etc. It also followed how the hospitals designated as exclusive "Covid-19 centres" were coping, how many additional health professionals were hired, the opening of new ICU beds, whether Personal Protective Equipment was available for health personnel and how Primary Health Care services were responding.

The success of the effort exceeded expectations: the Greeks complied with the "stay at home" order with forbearance and the transgressions were few and far between. Those who could work from home did so, schools and universities quickly adapted to distance teaching and many administrative matters that required visits in person to government offices were quickly shifted to on-line procedures. As a result, the rate of increase of new cases soon fell and so did the number of patients on ventilators. Daily deaths followed suit $(15,16)$.

Corroboration for the effectiveness of the policies implemented comes from the trend in overall mortality in the country: In comparison with previous years, no excess deaths were reported in the first six months of 2020 (17). This confirms that deaths in the community were not missed, whether due to Covid-19 or to other causes that may be attributed to people's fear of attending hospitals (18).

\section{The post-lockdown period}

On 4 May, after 6 weeks of lockdown that included the Greek Orthodox Easter and the long weekend of 1-3 May (a secular holiday), the gradual lifting of the emergency measures was initiated, starting with the cancellation of the "stay at home" order and its concomitant SMS messages and signed forms. Over the next few weeks, a gradual lifting of the restrictions was applied, albeit with the proviso that strict hygienic protocols would be observed, essentially keeping a safe physical distance and wearing a face mask whenever overcrowding might occur: shops opened; all religious services restarted; schools and universities resumed; beaches became accessible; bars, cafes and tavernas opened up, etc. By the end of June, the economy of the country had opened up for business (almost) as usual. One exception was that of incoming flights, which will be commented on later.

During the months of May and June, as restrictions were relaxed, social behaviour showed signs of a re- 
action by some young people who gathered in squares and outside bars, enjoying unofficial parties. The police intervened to disperse the crowds and to impose fines if bars and cafeterias were complicit in breaching the rules. Over this period, small clusters of cases continued to erupt all over the country, both from imported cases and from community transmission, mainly by asymptomatic carriers. These occurrences served as a strong reminder that, irrespective of results so far, the coronavirus had not disappeared and the emergence of a second wave is always possible if people do not behave responsibly. The identification of clusters was followed by an immediate "test-trace-isolate" procedure, including local lockdowns in specific villages and neighbourhoods. Fortunately, admissions to ICU did not increase and the deaths recorded were of patients who had been on a ventilator for some time.

\section{An explanation of the success of the endeavour}

The success in containing the pandemic was by no means inevitable. In order to explain the result achieved, one has to examine the behaviour of three main actors: the government, the academics and health professionals and the community.

The government of New Democracy was relatively new in office, having won the elections of 7 July 2019 with a clear majority in Parliament. It started its term of office with various initiatives to implement its manifesto without any major events. In the health sector, it promised that the ESY would be reorganized, letting it be understood that it would re-examine its relationship with the large private sector, in favour of the latter. There were two specific legislative initiatives regarding Public Health Services: a law reorganising the National Public Health Organization (EODY), previously known as the "Greek CDC", and a law on Public Health Services that was strongly criticized before its approval by Parliament (19). In the case of the pandemic, the government declared that it was going to follow the science and accept the advice of the Committee of Specialists. The Prime Minister made very few broadcasts, only to announce major decisions, the Minister of Health carried out focused public engagements and other Ministers, when asked about the pandemic, referred to the advice of the scientists.

The scientific community was well informed and almost unanimous in supporting the decisions regarding the pandemic. The Committee of Specialists was up to date on the scientific literature about the coronavirus, and it had open channels with the European Centre for Disease Control (ECDC) (20) and the World Health Organization (WHO) (21). In addition, all but very few of the academics and professionals who were interviewed daily on news bulletins and other TV programmes reinforced the messages pronounced by the Committee of Specialists, irrespective of whether they were members of the Committee or not. Even most important is that the doctors, nurses, ambulance staff and all other health professionals who work in the front line services of the state run ESY carried out their functions with professionalism and dedication, often beyond the call of duty. Their contribution should not be underestimated and it must be added that the public expressed their appreciation and respect on more than one occasion.

As already mentioned, the attitude of the public were surprisingly supportive, especially, in view of the experience of the fiscal crisis that Greece had gone through in the previous decade, when many people rejected the notion that the austerity was necessary to save the country's economy. When the European Union (EU), the International Monetary Fund (IMF) and the European Central Bank were called upon in 2010, 2012 and 2015 to bailout the economy and avoid a sovereign debt default, the Greeks were portrayed in the international press as an easy going, almost irresponsible people, who indulge in reckless spending. Were these negative stereotypes wrong or did something else happen? A credible interpretation is that in fact it was the experience of the fiscal crisis and the futility of believing and trusting in populist rhetoric that equipped the Greeks with the prudence and resilience required to accept the terms of the lockdown $(22,23)$ : having gone through the painful economic crisis, they were willing to make the necessary sacrifices to minimize the effects of the health crisis. They were willing to follow the government that showed determined leadership, as it had done on a previous, unrelated, occasion. Furthermore, they also accepted that it is best to listen to the specialists rather than believe conspiracy theories about the origins of the coronavirus and fake news about different miracle cures.

\section{The health services}

An important preoccupation was the awareness that after 10 years of cuts in the financing of the ESY, the health services were not ready to deal with a big surge of cases. It was long known that the number of ICU beds was below those required even for routine care (24); that the Primary Health Care services, required 
to manage patients outside hospitals, did not deploy the required number of family physicians in order to cover the whole population; that the Public Health Services, that are accountable to the country's 13 elected Regional administrations (25) do not possess the resources and capabilities required to monitor the spread in the community, to carry out contact tracing and to enforce all the necessary measures at a local level. These problems (and others) cannot all be attributed to the cuts in financing, many being the result of the chronic lack of a clear health strategy and the prevailing management style of "benign neglect": do not solve a problem unless it is urgent, since the solutions may incur political costs, while the benefits will only be apparent later on.

As regards the specific issues relevant to the management of the pandemic: the ICU beds were increased from 565 to 1015 by obtaining more ventilators and related equipment and by recruiting additional staff; specially designated Covid-19 Primary Health Centres were organized in the Athens conurbation to relieve the pressure on the hospitals; and the Public Health Services' functions of contact tracing and follow up were supplemented by an ad hoc service organized under the Civil Protection Agency.

\section{Protecting vulnerable populations}

During the pandemic, special consideration was given to protecting vulnerable populations, in particular the elderly in nursing homes, the refugees and migrants, the inhabitants of the islands and the Roma population of Greece. Looking briefly at each group, the nursing homes where many elderly people are cared for received strict quarantine orders from early March. The camps and other facilities where refugees and migrants are housed are often overcrowded and totally unsuitable for practising social distancing (26). They were placed under strict restrictions of movement so as to avoid importing the coronavirus into the encampments. The medical infrastructure and resources in the islands, especially the smaller ones, are by definition not suited to handling severely ill persons, especially in any sizeable numbers. So travel to the islands was allowed only for people who could prove their status as residents and for staff delivering essential goods and supplies. Finally, the Roma population of Greece, whose lifestyle does not facilitate social distancing, came into focus when a few clusters occurred in their neighbourhoods. These prompted the intervention of the
National Public Health Organization and the Civil Protection Agency. In turn, these provoked complaints about stigma and discrimination that were dealt with by dialogue with the Municipal Authorities and the leaders of the communities in the areas affected. The result was that any outbreaks were quickly contained and almost no deaths were recorded among all the groups above.

\section{The economy and tourism}

Everywhere, the lockdown has caused an economic shock, the size and extent of which cannot be accurately estimated because of the many uncertainties surrounding it (27). In the case of Greece, the pandemic struck just after the country had started to recover from the decade long recession, entering positive growth just in 2017. It is beyond the remit of the present paper to analyse the economic fallout. Suffice it to say that the government had announced a series of economic packages to support workers, employees and professionals who were furloughed, as well as to support the businesses and industries that lost their income, through no fault of theirs. The opposition parties, who provided unprecedented support to the measures against the pandemic, immediately expressed their objections, arguing that the proposals were inadequate and would not prevent a long term economic recession. At the same time, the issue of the economic support is under discussion at the level of the EU as a whole and of the Eurozone members in particular. This provides Greece with added financial security, while it has to negotiate with its partners in the EU about the size and the terms of the financial support it will receive.

Tourism is one sector where balancing the need to open up the economy with the health risks involved is paramount. With 33 million visitors in 2019 and contributing about $20 \%$ of the country's GDP, tourism is of major significance for the recovery of the economy (28). Certainly, health protocols have been addressed to hotels, other tourist accommodations, restaurants, etc., setting down the rules for safeguarding the health of visitors, staff and the local community. Herein lies a paradox: although the sacrifices of the Greeks render the country a safe destination, even safer than others, where will the visitors come from and how? How many airplanes will fly and under what restrictions? And the question on everybody's mind is whether the 
influx of tourists carries the risk of triggering a second wave of the outbreak. In any case, the issue of flights was discussed by the EU and it was decided that flights will resume on 1 July between the EU member states and those countries whose epidemiologic score is at least as good as the average score of the member states. At the same time, targeted tests for the coronavirus will be carried out on persons arriving who fulfil specific criteria. It remains to be seen how things will work out in practice.

\section{Concluding comments}

Greece responded to the challenges of the Covid-19 pandemic with commendable results. It took hard decisions very early in the pandemic wave, exhibiting excellent reflexes. It succeeded in "flattening the curve" and avoided too many excess deaths and admissions to ICU's. Its communication strategy succeeded in keeping the public informed and adhered to the requirements for transparency and public accountability. It provided decisive leadership in a democratic context which the public appreciated. Listening to the specialists was a novel and welcome experience for the country, where the advice of experts and "technocrats" is not usually heeded. The country could be proud that it emerged from the pandemic almost unscathed.

The future is still shrouded in many uncertainties. First and foremost is whether the strategy of containment of all clusters that emerge will succeed in preventing a major second wave and accompanying lockdown. In many ways, living with the restrictions at this stage is more difficult because much depends on the responsible behaviour of each individual rather than generalized prohibitions that apply to everybody. The questions about effective treatments and about an effective and safe vaccine will take a while to be answered, as will the question about the vaccine being available as a global public good, rather than a marketable commodity.

With respect to the health services of the country, the government has not made its position clear. Will it recognise that the response of the National Health System (ESY) was crucial in managing the pandemic and therefore will it re-examine its position regarding privatization of certain publicly provided services? Will it recognise that developing a family physician based, integrated system of Primary Health Care is a necessity? In a similar vein, will it recognise that the reorganisation and strengthening of the Public Health Services requires a comprehensive review of the recent Law on Public Health and includes investment in the training of specialists in Public Health - Social Medicine (29)?

Politically, during the first phase of the pandemic, there was a wide consensus about the measures applied. However, the economic downturn and the measures taken to soften the blow will certainly fuel the political debate. All the political parties will compete to convince the population that their proposals are better than those of their opponents. The basic choice will be between, on the one hand, a simplistic, populist approach that shifts the blame to others and promises easy solutions to complicated problems and, on the other hand, a more complex policy that weighs all the relevant factors and provides support to the economy in conjunction with some sacrifices by the citizens. In any case, the pandemic has shown that an adequate response to a major health crisis depends on the organization, finances and human resources of the public sector. In this respect, it is fundamental to consolidate the infrastructure of the welfare state, to secure sufficient funding and to strengthen its human resources before a crisis erupts. Whether Greece and other countries adhere to this strategy or not depends on both the citizens and their leaders.

\section{Received Date/Geliş Tarihi: 05.07.2020}

Accepted Date/Kabul Tarihi: 28.07.2020

\section{REFERANSLAR}

1. Zhang T, Wu Q, Zhang Z. Probable Pangolin Origin of SARS-CoV-2 Associated with the COVID-19 Outbreak. Curr Biol. 2020;30(7):1346-1351.e2. Erratum in: Curr Biol. 2020;30(8):1578.

2. Dos Santos Bezerra R, Valença IN, de Cassia Ruy P, Ximenez JPB, da Silva Junior WA, Covas DT, Kashima S, Slavov SN. The novel coronavirus SARS-CoV-2: From a zoonotic infection to coronavirus disease 2019. J Med Virol. 2020;29:10.1002/ jmv.26072. Epub ahead of print.

3. Li X, Zai J, Zhao Q, Nie Q, Li Y, Foley BT, Chaillon A. Evolutionary history, potential intermediate animal host, and cross-species analyses of SARS-CoV-2. J Med Virol. 2020;92(6):602-611.

4. Johns Hopkins University \& Medicine. Coronavirus Resource Center [internet]; 2020 [cited 2020 Jul 2]. Available from: https://coronavirus.jhu.edu/

5. Kronbichler A, Kresse D, Yoon S, Lee KH, Effenberger M, Shin JI. Asymptomatic patients as a source of COVID-19 infections: A systematic review and meta-analysis. Int J Infect Dis. 2020:S1201-9712(20)30487-2.

6. Huff HV, Singh A. Asymptomatic transmission during the COVID-19 pandemic and implications for public health strategies. Clin Infect Dis. 2020:ciaa654. doi: 10.1093/cid/ciaa654 
7. Cutler D. How Will COVID-19 Affect the Health Care Economy? JAMA. 2020;323(22):2237-2238.

8. Nicola M, Alsafi Z, Sohrabi C, Kerwan A, Al-Jabir A, Iosifidis C, Agha M, Agha R. The socio-economic implications of the coronavirus pandemic (COVID-19): A review. Int J Surg. 2020;78:185-193.

9. Ali S, Asaria M, Stranges S. COVID-19 and inequality: are we all in this together? Can J Public Health. 2020:1-2.

10. Arden MA, Chilcot J. Health psychology and the coronavirus (COVID-19) global pandemic: A call for research. Br J Health Psychol. 2020;25(2):231-232.

11. Devitt P. Can we expect an increased suicide rate due to Covid-19? Ir J Psychol Med. 2020:1-5

12. Kavanagh MM, Singh R. Democracy, Capacity, and Coercion in Pandemic Response-COVID 19 in Comparative Political Perspective. J Health Polit Policy Law. 2020:8641530. doi: 10.1215/03616878-8641530. Epub ahead of print. PMID: 32464665

13. Worldometer. COVID-19 Coronavirus Pandemic. [internet]; 2020 [cited 2020 Jul 2]. Available from: https://www.worldometers.info/coronavirus/

14. Wikipedia. COVID-19 pandemic in Greece [internet]; 2020 [cited 2020 Jul 2] Available from: https://en.wikipedia.org/wiki/COVID-19_pandemic_in_Greece

15. Greek Government. Covid19 - Greece. [internet]; 2020 [cited 2020 Jul 2] Available from: https://covid19.gov.gr/covid19-live-analytics/

16. National Public Health Organization. Covid-19 daily reports [internet]; 2020 [cited 2020 Jul 2] Available from: https://eody.gov.gr/category/covid-19/

17. European Mortality Monitoring Project. Graphs and maps. [internet]; 2020 [cited 2020 Jul 2]. Available from: https://www.euromomo.eu/graphs-andmaps/

18. Brenner MH. Will There Be an Epidemic of Corollary Illnesses Linked to a COVID-19-Related Recession? Am J Public Health. 2020;110(7):974-975.

19. Tountas Y, Tsouros A. Public Health in the 21st Century (In Greek) To Vima, [internet]; 7 March 2020. [cited 2020 Jul 2] Available from: https://www.tovima.gr/2020/03/07/opinions/i-dimosia-ygeia-ston-21o-aiona/
20. European Centre for Disease Prevention and Control. COVID-19 situation update for the EU/EEA and the UK [internet]; 2020 [cited 2020 Jul 2] Available from: https://www.ecdc.europa.eu/en/cases-2019-ncov-eueea

21. WHO Coronavirus disease (COVID-2019). Situation reports [internet]; 2020 [cited 2020 Jul 2] Available from: https:/www.who.int/emergencies/ diseases/novel-coronavirus-2019/situation-reports

22. Kollia E. What made the Greeks so resilient in the battle with the coronavirus? (In Greek) [internet]; 18 May 2020 [cited 2020 Jul 2] Available from: https://www.protagon.gr/themata/ti-ekane-tous-ellines-toso-anthektikous-sti-maxi-me-ton-koronoio-44342054760

23. Solano Gámez A. Resilience and Covid-19. Rev Colomb Obstet Ginecol. 2020;71(1):7-8.

24. Rhodes A, Ferdinande P, Flaatten H, Guidet B, Metnitz PG, Moreno RP. The variability of critical care bed numbers in Europe. Intensive Care Med. 2012;38(10):1647-53.

25. Philalithis A, Fotopoulos A, Trompoukis C. Public health - Social medicine: The history and the semantics of the term. Arch Hell Med, 2020;37(3):395405.

26. UNHCR. The UN Refugee Agency, Fact Sheet: Greece, 1-31 March 2019 [internet]; 2020 [cited $2020 \mathrm{Jul}$ 2] Available from: https://data2.unhcr.org/en/ documents/download/76284

27. European Commission. European Economic Forecasts, Spring 2020. Institutional Paper 125, [internet]; May 2020 [cited 2020 Jul 2] Available from: https://ec.europa.eu/info/publications/economic-and-financial-affairs-publications_en

28. Grech V, Grech P, Fabri S. A risk balancing act - tourism competition using health leverage in the COVID-19 era. Int J Risk Saf Med. 2020. doi: 10.3233/ JRS-200042. Epub ahead of print.

29. Philalithis A, The coronavirus pandemic: First thoughts for the day after (In Greek) Nea Kriti, [internet]; 2020 [cited 2020 Jul 2] April 27:6-7. Available from: https://www.neakriti.gr/article/apopseis/1575645/i-pandimia-tou-koronoiou-protes-skepseis-gia-tin-epomeni-mera/ 